\title{
THE COURSE AND OUTCOME OF A PREGNANCY WITH A PREMATURA PRETERM RUPTURE OF MEMBRANES DILEMA OR LIABILITY
}

\section{AUTHORS}

Jovanovic M. ${ }^{2}$, Dukanac Stamenković J. ${ }^{1}$

${ }^{1}$ Gynecology and Obstetrics Clinic of Clinical Centre of Serbia, Belgrade

${ }^{2}$ Gynecology and Obstetrics Clinic Faculty of Medicine Prishtina to Kosovska Mitrovica

\section{SUMMARY}

Preterm premature rupture of membranes (PPROM) is in obstetrics with incidence of $0,4 \%$ of , with risk for chorioamnionitis $35 \%$, risk for premature deli very $19 \%$, and sepsis risk of $1 \%$. Primary risk for fetus is pulmonal hypoplasia due to oligohydramnios in $29 \%$, RDS in $66 \%$ of such pregnancies, sepsis in $19 \%$, and contrac ture of extremities in $3 \%$. Fetal death is more than $30 \%$ of cases. Patient came to regular pregnancy check up in 22 th week of gestation. US exami nation revealed decreased fluid volume AFI 50, with regular morphology and fetal dynamic. She was admitted to hospital. She was given cortico-steroids and antibiotics. In further course of pregnancy amniocentesis was performed in 32th week of preg nancy to rule out the infection and to check pulmonal maturity. In absence of infection and lung maturity pregnancy was continued until 36th week of gestation when Cesarean Section was. Baby went well and is now healthy child in the age of three. Some studies suggested that delivery can be significantly prolonged. In our case we menaged to gain 14 weeks, from 22th to 36th gestational week. Firstly gynaecologyst nightmare to ask the woman is she accept therapy. The aim is to deliver a healthy child without neurological and other consequen ces and mother with preserved reproductive function. Controversy still exists when is the appropriate time to finish pregnancy with prolonged PPROM.

Keywords: oligohydramnios, respiratory distress, therapy, outcome.

\section{INTRODUCTION}

Preterm premature rupture of membranes (PPROM) is in obstetrics with incidence of $0,4 \%$ of , with risk for chorioamnionitis $35 \%$, risk for premature deli very $19 \%$, and sepsis risk of $1 \%$. Primary risk for fetus is pulmonal hypoplasia due to oligohydramnios in $29 \%$, Respiratory Distress Syndrom(RDS) in $66 \%$ of such pregnancies, sepsis in $19 \%$, and contracture of extremities in $3 \%$. Fetal death is more than $30 \%$ of cases.

\section{CASE REPORT}

On the 3th of February 2010, a primigravida D. C. (1973) from Belgrade who was in 22th week gestation came to Institut of Gynecology and Obstetrics(IGO) of Clinical Centere of Serbia, Belgrade on a regular checkup. At an ultrasonographic examination a lower level of amniotic fluid AFI - 50 was noticed, with a normal morpholgy and dynamics of the fetus.

On the same day, she was admited to hospital with intensive supervision and with complete laboratory tests (C - reactive protein (CRP), complete blood analysis, wider biochemical parameters: urea, creatinin, lactal dehydrogenesis, alkaline phosphatasis, direct and indi- rect bilirubins, transaminases, cervical and vaginal smears, urin and urino culture.

Before her pregnancy, the patient was diagnosed with hypofunction of thyroid gland so she was already receiv ing Tivoral $50 \mathrm{mg} / 24 \mathrm{~h}$ and during the pregnancy she was diagnosed with gestational diabetes A1. Microbiological result of cervical and vaginal smear implied bacterial vaginosis and the results of urin showed Escherihia Colli. Antibiotic therapy included amp. Longacef $2 \mathrm{~g} / 24 \mathrm{~h}$ and vaginal tablets Orvagil 1 in the evening with iv. rehydration. The parameters of the infection were moniterd daily (CRP and leukocytes with measuring of basal temperature). $C R P<5$, Le 7.000 , but did not go over 36.70C.

Biophysical profile (BPF) was done every day with measuring of amniotic fluid index (AFI) was between 30 and 40 and in the 33 weeks' gestation it was 15 . In the 24th week of gestation with the decision of doctors from Perinatal medicine, the maturation of fetal lungs began with $4 \mathrm{mg} / 6 \mathrm{~h}$ corticosteroides in the next 24 hours. The parameters of infection were stable.

In the 27th week of gestation a fetal echosonofraphy was performed as a part of a regular perinatal screening and it implied normal echocardiographic finding. Ultrasono graphic result in that period showed normal dynamics of the fetus. 
Microbiological result of repeated cervical and vaginal smear showed Klebsielle and Enterobacter in the smears and Escherihia Colli in urin test. According to antibio- gram the therapy was Panclav tbl. $625 \mathrm{mg} / 8 \mathrm{~h}$ and vag. Chloramphenicol a $250 \mathrm{mg} 1$ in the evening. Control smears sterile, parameters which could show infection stable.In the 32 week gestation the amniocentesis was performed. The sample was sent to a microbiologi- cal examination and to determine the maturity of fetal lungs. The lecitin - sphyngomyelin ratio was $1: 1,5$ and microbiological result showed sterile fetal amniotic fluid.

Obstetric result from the moment of reception and in further course was stable. In the 35 weeks' gestation the patient was sent to doctors at Perinatal medicine who decided to do Cesarean section in the 37 weeks' gestation with intensive monitoring of mother and fetus and intensive monitoring of infection. In the 36 weeks' gestation the patient suffered from contractions and scarce bleeding. Basal temperature was $38,50 \mathrm{C}$, non stress test of fetus (NST) implied increase of basal frequency (around 170 a minute). During obstetric examination it was diagnosed that the labour started with first signs of chorioamniotis. On the same day the Cesarean section was performed and alive, term newborn was born Apgar scor( As) $7 / 8$ with measurements $3600 / 53 / 35$, on birth cyanotic, dyspneic. Because of the possibility of perinatal infection the bacteriological, laboratory, radio logical and echosonographic test were performed. The baby was admitted in to Neonatal Intensive Care Unit and on the fourth day was admitted into semi-intensive care unit. Escherihia Colli was isolated From nasopharynx and eye, which was treated with antibotics and oxygenotherapy, IV infusion, with a good reaction. The parameters of infection (CRP, Le), after the therapy was included, were in decline. Neurological results: present hypotonia of left side of the body without pathological findings. Important facts: complete blood test and gas analysis within the limits of findings and nuclear magnetic resonance (NMR) of head, torticolis left, luxation of left hip.

The mother was transferred from semi-intensive unit in a good state, afebrile. After 24 hours, increase of basal temperature to $380 \mathrm{C}$ was diagnosed. Biochemical microbiological parameters showed presence of infectious agent (Escherihia Colli in uterus smear, lochia and wound), hemoculture - Le - in reference values. Procalcitonin was $<0.05$ which implied that the patient was not in septic condition.

Antibiotic treatment was included according to the antibiogram: Conet $1 \mathrm{~g} / 6 \mathrm{~h}$, Vancogal $1 \mathrm{~g} / 12 \mathrm{~h}$ iv infusion, Fraxiparin $0.6 \mathrm{ml} / 12 \mathrm{~h}$. Despite the therapy, the patient had fever in the next 8 days. It led to wound dehiscence which was treated with Amikacin $2 \mathrm{~g} / 24 \mathrm{~h}$ with a good reaction of the patient. In the next few days the parameters of infe- ction (CRP, Se, VFK, Le) were falling and so did the fever. A control ultrasound exa- mination showed that uterus was in good involution without a presence detritus and coagulum.

After seven days, microbiological smears of uterus and lochias were repeated and the result was sterile. Resuture of the wound was performed. Twenty days after childbirth recovered patient and baby were discharged from Institute of Gynecology and Obstetrics.

The baby's condition was intensively monitored at University Children Clinic and at the Institute of Neourology faculty of Medicine at Clinical centre of Serbia, Belgrade. In the 7 th month, the baby was diagnosed with luxation of left hip and worked Repositio chirurgica coxae $\sin$. Sec.Ludolf was performed. Neurological result with EEG of head was normal. The child is regulary controlled at University Children Clinic in Tirshova and at Institute of Neurology at Clinical centre of Serbia, Belgrade. The baby is in good overall condition and without consequences. After dismissing from the hospital mother was in the good condition, and consequent follow ups in 2 years time showed no thing of any ginecological complication.

\section{DISCUSION}

Premature preterm rupture of membranes (PPROM) prior to fetal viability is a unique and relatively rare problem that is often difficult to manage. It occurs in less than $0.4 \%$ of all pregnancies. The major risk is infection, namely chorioamnionitis, which occurs in about $35 \%$ cases. In $19 \%$ it causes abruptuion an in $1 \%$ it causes sepsis. $[1,2,3,4,5]$, The major morbidity in the fetus is lethal pulmonary hypoplasia with oligohydramnios, which occurs in $29 \%$ of cases. Other morbidities are respiratory distress syndrome (RDS) (66\%), sepsis (19\%), IVH (5\%), and contractures $(3 \%) \quad[4,5,6,7,8,9]$. Fetal death is common and occurs in more than $30 \%$. Older studies have reported that approximately $50 \%$ of pregnancies with PPROM deliver in next seven days. More recent studies have shown better prognosis. With appropriate therapy and conservative management, $30 \%$ of preg- nancies can be prolonged up to 5 weeks $[4,5,7,8,10,11,12]$. PPROM between 13-26 week of gestation has a poor prognosis although more recent studies have reported encouraging facts. (Waters TP, Mercer BM. The management of preterm premature rupture of the membranes near the limit of fetal viability) $[11,12,15,17]$. Survival varies with gestational age at diagnosis, from $12 \%$ when diagnosed at $16-19$ th week, to as much as $60 \%$ when dia- gnosed at 25-26th week. Expectant management may be appropriate in selected patients who are well informed and educated about the risks and the dismal prognosis for the neo- nate $[2,4,5,6,7,9,11]$.

Maternal safety should be the primary concern. Amniocentesis can pro- vide information about lung maturity and to give answer of presence of infectious agent in amniotic fluid. This invasive procedure, since the amount of fluid is scant, should be performed by experienced individuals and with obligatory explanation to mother about the potential risks which happen with this procedure $[2,4,5,6,7,9,10,11]$.

The use of corticosteroids to accelerate lung maturity should be considered in all patients with PPROM with a risk of infant prematurity from 24-34 weeks' gestation. The use of tocolysis for 48 hours to administer steroids and allow acceleration of fetal lung maturity has been proposed and is being used by some obstetricians. No data support the efficacy of this practice and, as such, when used in this manner, the lack of evidence to support this practice should be discussed with patients to allow informed consent prior to the use of tocolytics and the potential complications and side effects. A positive outcome of pregnancy with premature preterm rupture of membranes is possible with modern peri- natalogical protocols, but still has high risks for mother and for baby $[1,2,3,6,7,10,11,12]$. The aim of perinatology in these cases is to deliver a healthy baby capable of living with- 
out neurological and other sequels, and on the other hand a healthy mother with saved reproductive system. Infection is still a leading risk factor for an unfavourable outcome of these pregnancies because there are more and more kinds of microorganisms resistant to antibiotherapy (besides modern pharmacotherapy) which largely increases perinatal morbidity and mortality of baby and mother. The initial step in management of PPROM is patient's consent.

Two of the largest studies that have looked at the efficacy of antibiotic use in PPROM are the National Institute of Child Health and Hum an Development (NICHDMFMU) and the ORACLE trial. In the NICHD study, intravenous antibiotics were used for 48 hours - ampicillin $2 \mathrm{~g}$ / $6 \mathrm{~h}$ and erythromycin $250 \mathrm{mg} / 6 \mathrm{~h}$. The patients were then placed on oral amoxicillin $250 \mathrm{mg} / \mathrm{8h}$, erythromycin $250 \mathrm{mg} / 8 \mathrm{~h}$ to complete a 7-day course of antibiotic therapy. In this study, the control group, compared with the antibiotic group, had a significantly shorter duration of latency and much greater risk of chorioam- nionitis and neonatal sepsis. This therapy refers to beta hemolytic streptococcus group $B$. The intensive monitoring of mother and fetus is necessary, with daily controls of para- meters of infection, weekly cervical and vaginal smear, daily measuring of level of amni- otic fluid $[3,9,10,11,12]$.

The maturation of fetal lungs with corticosteroids in these cases is necessary avoid RSD but it is not recommended before 24 weeks' gestation. The use of corticoste- roids in patients with PPROM is solely to acceler- ate lung maturity but on the other hand it can increase risk of infection. However, current studies in NICXD do not support this concern which is based only on individual studies and meta-analysis. On the other hand, the rates of respiratory distress syndrome (RDS), necrotizing enterocolitis, and fetal intraventricular hemorrhage are decreased. Team work is necessary, including Neonatal unit, and tertiary institutions have a priority in these cases $[4,5,6,7,9,10,11]$.

PPROM in 22 weeks' gestation with a favourable outcome after 14 weeks is for now a unique case in IGO of Clinical Centre of Serbia, Belgrade and represents the suc cess of the entire team from Institute of Gynecology and Obstetrics of Clinical Centre of Serbia, Belgrade, that is High-Risk Pregnancy Unit, which contributed with their unsel fish effort and knowledge to de liver a healthy baby capable for life after 14 weeks with PPROM.

\section{CONCLUSION}

Prior to every effort to prolong pregnancy in cases of severe PPROM perents sould be in details thoroughly informed about the riscs and prognosis for mother and child and give their written consent. We menaged to prolong pregnancy after PPROM from 22th to 36th week of pregnancy using antibiotics and corticosteroids and performed Cesarean Section giving birth to healthy child with minor consequences for mother. Child is now 3 years of age and is getting on fine.

\section{REFERENCES}

1. Jazayeri A, Jazayeri MK, Sutkin G. Tocolysis does not improve neonatal outcome in patients with preterm rupture of membranes. Am. J. Perinatal, May 2003: 20(4):189-93.

2. Mercer BM. Preterm premature rupture of the membranes: diagnosis and manage ment. Clin Perinatol. Dec 2004;31(4):765-82.

3. Mercer B, Milluzzi C, Collin M. Periviable birth at 20 to 26 weeks of gestation: proximate causes, previous obstetric history and recurrence risk. Am J Obstet Gynecol. Sep 2005;193(3 Pt 2):1175-80.

4. Agard-Tillery KM, Nuthalapaty FS, Ramsey PS, Ramin KD. Preterm premature rupture of membranes: perspectives surrounding controversies in management Am J Perinatol. Aug 2005;22(6):287-97.

5. Simhan HN, Canavan TP. Preterm premature rupture of membranes: diagnosis, evaluation and management strategis. BJOG. Mar 2005;112 Suppl 1:32-7

6. Hartling L, Chari R, Friesen C, Vandermeer B, Lacaze-Masmonteil T. A systematic review of intentional delivery in women with preterm prelabor rupture of membranes. J Matern Fetal Neonatal Med. Mar 2006;19(3):177-87.

7. Pasquier JC, Bujold E. A systematic review of intentional delivery in women with preterm prelabor rupture of membranes. J Mat ern Fetal Neonatal Med, Jul2007: 20(7):567-8.

8. Muris C, Girard B, Creveuil C, Durin L, Herlicoviez M, Dreyfus M. Management of premature rupture of membranes before 25 weeks. Eur J Obstet Gynecol Reprod Biol. Apr 2007;131(2):163-8.

9. Mercer BM. Is there a role for tocolytic therapy during conservative management of preterm premature rupture of the membranes? Clin Obstet Gynecol. Jun 2007; 50(2):487-96.

10. ACOG Practice Bulletin No. 80: premature rupture of membranes. Clinical management guidelines for obstetrician-gynecologists. Obstet and Gynecol. Apr: 2007;109(4):1007-19.

11. ACOG Committee Opinion No. 402: Antenatal corticosteroid therapy for fetal matu ration. ObstetGynecol. Mar 2008;111(3):8057.

12. Waters TP, Mercer BM. The management of preterm premature rupture of the mem branes near the limit of fetal viability Am $J$ Obstet Gynecol. Sep 2009;201(3):230-40. 


\section{SRPSKI}

\section{TOK I ISHOD TRUDNOĆE SA PRETERMINSKOM PREVREMENOM RUPTUROM PLODOVIH OVOJAKA DILEMA ILI OBAVEZA}

Jovanovic M. ${ }^{2}$, Dukanac Stamenković J. ${ }^{1}$

${ }^{1}$ Klinika za ginekologiju i akušerstvo Kliničkog centra Srbije, Beograd

${ }^{2}$ Klinika za ginekologiju i akušerstvo Medicinskog fakulteta u Prištini, Kosovska Mitrovica

\section{SAŽETAK}

Preterminsko prevremeno pucanje plodovih ovojaka javlja se u manje od 0,4\% svih trudnoća, rizik od horioamnionitisa iznosi $35 \%$, od prevremenog porođaja 19\%, rizik od sepse je 1\% . Kod fetusa glavni uzrok morbiditeta je hipoplazija pluća uz pridruženi oligoamnion koji se javlja u 29\% slučajeva ,respirtorni distres koji se javlja u $66 \%$, sepsa ( 19\%), kontraktura ( $3 \%$ ) slucajeva. Fetalna smrt je česta i javlja se kod više od 30\% slučaja. Prvorotka, 1973 iz Beograda javlja se 03.02.2010 god. u 22. nedelji gestacije u IGA KCS na redovnu zakazanu kontrolu. Pri UZ pregledu prime- ćena je manja količina plodove vode AFI-50, uz normalnu morfologiju i dinamiku ploda. Trudnica je odmah hospitalizovana i laboratorijski obrađena. Trudnoća je dalje vođena antibiotskom terapijom i kortikosteroidima. Porođena je u 36 nedelji gestacije carskim rezom. Ranije studije su ukazivale da se PPRPOM u oko 50\% trudnoća završavalo u narednih sedam dana. Novije studije ukazuju da se porođaj može duže odgo- diti, ali samo u kliničkim uslovima, uz odgovarajući permanentni stručni nadzor i prime- nu adekvatne terapije. U našem slučaju trudnoća je produžena 14 nedelja ( od 22. - 36. nedelje gestacije) uz relativno manje komplikacije. Zadatak akušera u ovakvim slučajevima je dobra procena stanja trudnice i ploda i njena saglasnost da se pristupi lečenju, ali samo u odgovarajućoj ustanovi gde se može pratiti stanje majke i ploda, kako laboratorijski tako i klinički. Cilj je dobiti zdravo i za život sposobno dete bez neuroloških i ostalih sekvela i reproduktivno zdravu majku.

Ključne reči: oligoamnion, horioamnionitis, respiratorni distres, terapija, ishod. 